\title{
Using the Power of Word-Of-Mouth to Leverage the Effect of Marketing Activities on Consumer Responses
}

\author{
Martensen, Anne; Mouritsen, Jan
}

\author{
Document Version \\ Accepted author manuscript \\ Published in: \\ Total Quality Management \& Business Excellence
}

DOI:

10.1080/14783363.2016.1187996

Publication date:

2016

License

Unspecified

Citation for published version (APA):

Martensen, A., \& Mouritsen, J. (2016). Using the Power of Word-Of-Mouth to Leverage the Effect of Marketing Activities on Consumer Responses. Total Quality Management \& Business Excellence, 27(7-8), 927-943. https://doi.org/10.1080/14783363.2016.1187996

Link to publication in CBS Research Portal

\section{General rights}

Copyright and moral rights for the publications made accessible in the public portal are retained by the authors and/or other copyright owners and it is a condition of accessing publications that users recognise and abide by the legal requirements associated with these rights.

\section{Take down policy}

If you believe that this document breaches copyright please contact us (research.lib@cbs.dk) providing details, and we will remove access to the work immediately and investigate your claim. 


\section{Using the Power of Word-Of-Mouth to Leverage the Effect of Marketing Activities on Consumer Responses} Anne Martensen and Jan Mouritsen

Journal article (Post print version)

Cite: Using the Power of Word-Of-Mouth to Leverage the Effect of Marketing Activities on Consumer Responses. / Martensen, Anne; Mouritsen, Jan. I: Total Quality Management \& Business Excellence, Vol. 27, Nr. 7-8, 2016, s. 927-943.

This is an Accepted Manuscript of an article published by Taylor \& Francis in Total Quality Management \& Business Excellence on 24 May 2016, available online: http://www.tandfonline.com/10.1080/14783363.2016.1187996

Uploaded to Research@CBS: May २०17 


\title{
USING THE POWER OF WORD-OF-MOUTH TO LEVERAGE THE EFFECT OF MARKETING ACTIVITIES ON CONSUMER RESPONSES
}

\begin{abstract}
Research has studied Word-Of-Mouth (WOM) and the 4P marketing activities separately with no attention to how these two processes simultaneously influence consumer responses. This is unfortunate as a firm's marketing activities may also mobilize WOM which then can leverage the activities' effect on consumer responses. The present study fills this research gap and investigates how WOM mediates the relationship between the 4Ps and consumers responses using Partial Least Square on survey data with 400 broadband customers. Findings show that the 4Ps influence consumer responses directly and that this effect is leveraged when WOM mediates the relationship. The 4Ps primarily mobilize positive WOM (PWOM), making PWOM the strongest mediator. This has implications for marketing and communication strategies, as the 4Ps have to mobilize WOM and influence consumer responses directly. This challenges the composition of the 4Ps and how to design the marketing message so it is appealing for consumers to bring into their social milieu so WOM can take place. It also underlines the necessity to add PWOM as a fifth $P$, so the different marketing activities' effect can be amplified by the power of WOM and brands can be created as much out of PWOM as out of marketing activities.
\end{abstract}

Key words - Word-of-mouth, Marketing activities, Brand value chain, Brand attitude, Purchase intention, Structural equation model, Mediation, Survey

\section{Financial disclosure}

Data collection was provided by Wilke Research A/S, Denmark. 


\section{Introduction}

Consumers often discuss a firm, its brand and its marketing activities. This "act of exchanging marketing information among consumers" (Chu and Kim 2011, p. 48) - or Wordof-Mouth (WOM) - evaluates the firm's ability to make the brand promise real, and it adds beliefs, preferences and experiences that may help consumers to better understand the firm's marketing messages and guide them when making choices (East et al. 2008; Libai et al. 2011). Consumers refer to marketing activities in almost every second WOM-conversation (Keller 2007). Previous research has studied WOM and marketing activities separately with no attention to how these two processes are related and simultaneously influence consumer responses in the form of brand attitudes, purchase intentions and actual behavior (Bruyn and Lilien 2008; Nyilasy 2006; Sweeney et al. 2008). This is problematic since the relationship between the two processes may give rise to three important effects.

First, WOM may extend and leverage the effect of the firm's marketing activities beyond the planned time period as a consequence of bringing the marketing activities into the consumers' social milieu.

Second, the knowledge acquired from WOM "plays an essential role in changing consumers' attitudes and behavior towards products and services" (Chu and Kim 2011, p. 48). When consumers exchange information, opinions and experiences about a brand (WOM), WOM becomes a substitute for direct experiences and a quick way for the consumer to search information, clarify questions and understand specific elements of the firm's marketing activities (Allsop et al. 2007; Keller 2007).

Third, how WOM changes consumers' responses depends on the valence of WOM. Previous research find that positive WOM (PWOM) and negative WOM (NWOM) have asymmetric effect on consumer responses, but also that no consensus exist on which effect is the dominating one (Ahluwalia 2002; East et al. 2008). This indicates that variation exists in 
PWOM and NWOMs mediating effect between marketing activities and consumer responses.

These three important effects make the following research question relevant to study: How do PWOM and NWOM mediate the marketing activities effect on consumers' responses?

This study contributes by showing how WOM helps create the value of the brand. Marketers may find this knowledge important when developing general marketing strategies for the 4Ps, planning integrated marketing communication strategies, and designing marketing messages that is appealing for consumers to take into the social milieu, so WOM is mobilized.

\section{Literature review}

\subsection{The conceptual model}

The Brand Value Chain (BVC)-model proposed by Keller and Lehmann (2003) and later adapted by other researchers (Gupta and Zeithaml 2006; Rust et al. 2004) suggests that marketing investments influence consumers' mindset which, in turn, influences the brands' market performance and shareholder value. The customer mindset construct includes "everything that exists in the minds of customers with respect to a brand (e.g., thoughts, feelings, experiences, images, perceptions, beliefs, and attitudes)" (Keller and Lehmann 2003). In order to allow an individual's attitude formation processes to be socially influenced we extend the BVC-model by adding WOM as a mediator between a firm's marketing activities and the consumer's mindset (see Figure 1) (East et al. 2008; Libai et al. 2010). WOM may produce desirability, acceptability and status in a social group since it articulates preferences related to norms that the group will sanction positively and negatively (Wu and Wang 2005).

Marketing activities are related to McCarthy’s (1964) well-known 4Ps model: Product, Price, Place and Promotion. From a consumer's point of view, the marketing activities are designed to provide value, communicate the value and deliver the value (Bradley 2003). 


\section{Insert Figure 1 about here}

Research has partially studied most of the links in Figure 1 from a sender's perspective, cf. Table 1 . This study takes a receiver's perspective. Receivers' motivation for listening to WOM is often based on three types of values: utilitarian value, economic value and social value. Utilitarian value relates to information exchange, where individuals can enhance their skills and knowledge to make better-informed decisions, leading to improved perceived economic value of that specific product. WOM also enhances consumers' social value through creating and sharing a bond with other group members lowering the social risk of making a "wrong" purchase decision (Hung and Li 2007).

\section{Insert Table 1 about here}

\subsection{WOM}

\subsubsection{WOMs mediating effect}

When WOM mediates the relationship between marketing activities and consumers' responses WOM will amplify the marketing message's original effect on consumers' responses. The argument is that WOM broadens the discussion of the firm's offer by including experiences, preferences, opinions and acceptability. Hence, WOM adds to or detracts from the brand promise seen in the firm's marketing message, which changes the marketing message's effect on consumers' responses.

\subsubsection{PWOM versus NWOM}

Previous research shows that consumers respond asymmetrically to PWOM and NWOM. Some researchers argue that consumers are more prone to believe negative information than positive (Fiske 1980; Huang et al. 2011; Kahneman and Tversky 1979). For example, most brand messages tend to be positive, but when negative information distorts a positive message it often causes attention (Chakravarty et al. 2010). Here we claim that NWOM has a stronger mediating effect on consumers' responses than PWOM. 
Other researchers argue that PWOM has a greater effect on consumers' responses than NWOM based on theories of brand loyalty. Loyal customers are more likely to engage in PWOM, since PWOM confirms their current choice of brand, and leads to a state of mental balance (Ahluwalia 2002; Godes and Mayzlin 2004). Loyal customers may be less likely to accept or notice NWOM about the brand, since this contradicts previous beliefs, attitudes and behavior and leads to a state of mental imbalance. East et al. (2008) find that PWOM is 76\% more influential than NWOM within established product categories and well-known brands. Here we claim that PWOM has a stronger mediating effect on consumers' responses than NWOM.

Yet other researchers like Ahluwalia (2002) and Charlett and Garland (1995) find that PWOM and NWOMs impact on consumers' brand attitudes and purchase intentions are of the same size.

\subsection{WOMs mediation of the 4Ps}

\subsubsection{WOMs mediation of the product}

Product is understood both as the physical product (functionality, features, quality, brand, etc.) (Garvin 1984) and as the delivered service (complaint management, after sales service, employee competences and affections, etc.) (Parasuraman et al.1988). This classification is well-known and applied in customer satisfaction research, where the impact of perceived product and service quality on brand attitude (including customer satisfaction) is welldocumented (Fornell et al. 1996; Kristensen et al. 2000).

The relationship product/service quality $\rightarrow \mathrm{WOM}$ is discussed in the literature, but from a sender's perspective. Satisfied or dissatisfied customers share their positive and negative experiences with others, leading them to recommend and advice against the brand (Arora 2007). Keller Fay Group (2009) find that consumers often participate in WOM if the product or service is worth talking about, as reflected by products/services that fulfill consumers' 
needs, being innovative or easy to talk about. Engel et al. (1969) find that both product and service quality elements mobilize WOM. Cengiz and Yayla (2007) find a direct and positive relationship between product quality and PWOM, whereas Lewis (1983) finds that poor service quality often mobilizes NWOM. Furthermore, Fornell et al. (1996) and Kristensen et al. (2000) find that product and service quality influence customer satisfaction which in turn stimulates senders' to provide PWOM. When a receiver is in a decision process he/she may pay attention to information about product/service quality that can help him/her to make the best and most informed decision. Thus, we argue that product/service quality $\rightarrow \mathrm{PWOM} / \mathrm{NWOM}$ also exist in a receiver's perspective.

Based hereon and the documented relationships $\mathrm{P}(\mathrm{N}) \mathrm{WOM} \rightarrow$ brand attitude from previous research, we define the following hypotheses:

H4d: PWOM partially mediates the relationship between (1) product quality and brand attitude; (2) service quality and brand attitude

H4e: NWOM partially mediates the relationship between (1) product quality and brand attitude; (2) service quality and brand attitude

\subsubsection{WOMs mediation of place}

Place in this study is reflected by the location of stores and the quality of the firm's website (Perreault et al. 2008). If the product is easily accessible when desired by the consumer, it may mobilize PWOM and have slightly positive or neutral impact on brand attitude. Having problems finding a place to buy the product when desired, it may mobilize NWOM.

Research from a sender's perspective shows a positive and direct relationship between place and PWOM (Cengiz and Yayla 2007), and between website quality, brand attitude and PWOM (Martensen et al. 2004).

Hence, the following hypotheses: 
H5d: PWOM partially mediates the relationship between (1) location of stores and brand attitude; (2) the firm's website and brand attitude

H5e: NWOM partially mediates the relationship between (1) location of stores and brand attitude; (2) the firm's website and brand attitude

\subsubsection{WOMs mediation of price}

Price is extensively discussed in the literature (Cengiz and Yayla 2007; Monroe and Krishman 1983; Richins 1983; Zeithaml 1984). From a customer's perspective, price is perceived as one of the most important determinants in the decision making process (Chang and Wildt 1994), why we argue that price, reflected by competitive prices, discounts, value for money, etc., influences consumers brand attitude and mobilizes WOM. The relationship price $\rightarrow$ brand attitude is well-documented in the literature (Monroe and Krishman 1983; Richins 1983; Zeithaml 1984). Studies of the relationship price $\rightarrow$ WOM from a receiver's perspective are more limited. Richins (1983) finds that higher prices increase the probability of NWOM, if the product does not live up to expectations. Cengiz and Yayla (2007) find that price has a strong impact on PWOM.

Thus we propose that:

H6d: PWOM partially mediates the relationship between price and brand attitude H6e: NWOM partially mediates the relationship between price and brand attitude

\subsubsection{WOMs mediation of promotion}

Promotion in this study is operationalized as perceived advertising content (message) and general product communication from the firm. Several researchers argue that promotion influences WOM, but only few studies have actually documented the relationship (East et al. 2005; Gelb and Johnson 1995; Graham and Havlena 2007). Bayus (1985) and Cengiz and Yayla (2007) studies show how an increase in exposure to advertising and promotion mobilize PWOM. King and Tinkham (1989) demonstrate how new, ambiguous or innovative 
outdoor advertising mobilizes WOM. Keller Fay Group (2009) finds that 3.3 billion brand impressions are created each day in the US as a consequence of WOM, and 20\% hereof are mobilized by advertising. Graham and Havlena (2007) find that the interplay between advertising and PWOM varies depending on type of media channel and industry. Most of these studies take a sender's perspective, but we take a receiver perspective. We argue that the findings are still applicable to a receiver perspective, because it is the same process and the same instruments that are at play, just viewed from a receiver's perspective.

Thus, we state that:

H7d: PWOM partially mediates the relationship between (1) advertising content and brand attitude; (2) the general product communication and brand attitude H7e: NWOM partially mediates the relationship between (1) advertising content and brand attitude; (2) the general product communication and brand attitude

\section{Data and methodology}

\subsection{Measures and data collection}

All measurement scales are either adopted or inspired by scales from previous research (see Appendix).

To validate the model and test the hypotheses, an online-based survey about a large broadband service provider was conducted. Data was obtained from an online research panel comprising 25,000 members, and a stratified sample of 2,663 persons between 18 and 55 years of age was selected. An e-mail invitation was sent to this sample, containing an embedded URL link. In total 1,547 members was obtained, resembling to a response rate of $58.1 \%$ of the invited panelists. A total of 379 valid interviews were conducted and the sample was representative. All respondents were familiar with the firm and its advertising campaign, and had been told positive or negative things about the firm from family members, friends, acquaintances, colleagues, neighbors, etc. 


\subsection{Analytical approach and test of the model}

The conceptual model in Figure 1 is analyzed as a structural equation model using the Partial Least Squares (PLS) method (Chin 1998; Fornell and Cha 1994; Tenenhaus et al. 2005) and the software SmartPLS (Ringle et al. 2005) for estimation purposes. PLS is distribution-free and robust and appropriate for complex models (Chin 1998; Hulland 1999; Reinartz et al. 2009). All indicators were specified as reflective (Fornell and Cha 1994). Item reliability, composite reliability and AVE were all above required standards (see Appendix) and discriminant validity showed that the square root of AVE of a latent variable were greater than the correlations between the latent variable and any other latent variable in the model (Chin 1998; Fornell and Larcker 1981; Hulland 1999). Table 2 summarizes the result of the mediation tests of the model in Figure 1. For each hypothesized mediation, the estimated effects a, b, and c' are indicated as well as the calculated values of ab and total effect c. The mediation share and Sobel's Z-test are calculated and the result in relation to partial, complete or no mediation is indicated for each hypothesis. To evaluate the final PLS model $\mathrm{R}^{2}$ values are examined for brand attitude (.81) and purchase intention (.58), indicating very good and good explanations and overall fit (Chin, 1998; Hulland, 1999) (see Appendix). Overall, our empirical application supports the proposed model in Figure 1 and the associated measurement system.

\section{Insert Table 2 about here}

\section{Results}

Findings indicate that it is relevant to add PWOM and NWOM to Keller and Lehmann's (2003) BVC-model. Research in WOM and the 4Ps have neglected that both phenomena appear simultaneously where WOM is a mediator.

\subsection{Marketing activities' ability to mobilize WOM}


Marketing activities mobilize WOM, indicated by half of the direct relationships between marketing activities and PWOM/NWOM are significant (hypotheses $4 \mathrm{a}_{1}, 4 \mathrm{~b}_{1}, 4 \mathrm{~b}_{2}, 5 \mathrm{a}_{1}, 6 \mathrm{~b}, 7 \mathrm{a}_{1}$ and $7 b_{2}$ are supported).

PWOM is mobilized by three marketing activities: Product quality, advertising content and store location. High quality products $(\beta=.36)$, reflected by fulfilling the advertised speed and by having high functionality is the main mobilizer of PWOM. This supports Cengiz and Yayla (2007), Arona (2007) and Keller Fay Group (2009) findings. However, advertising content, such as a relevant and touching message $(\beta=.19)$ and accessible and sufficient number of stores $(\beta=.15)$ are also important mobilizers of PWOM. This supports Graham and Havlena (2007), Keller Fay Group (2006), and Cengiz and Yayla (2007)'s findings. Price does not influence PWOM as documented in Cengiz and Yayla's (2007) study.

NWOM is mainly mobilized by product quality $(\beta=-.31)$ and general product communication $(\beta=-.25)$, whereas service quality $(\beta=-.09)$ and price $(\beta=-.08)$ are relatively less able to mobilize NWOM. Price and service quality's low influence on NWOM contradicts Lewis (1983) and Richin's (1983) findings.

One explanation for price having no effect on PWOM, and only minimal impact on NWOM may be that affordable prices have been the main message in the firm's advertising campaigns. From a theoretical perspective, high quality products and services may be seen as a basic premise for being an important player on the market and not price.

\subsection{Marketing activities direct influence on brand attitude}

Brand attitude is directly influenced by all marketing activities except store location and product communication. Brand attitude is mainly formed by the core product, i.e. product and service quality $(\beta=.27$ and $\beta=.39)$. If the firm is able to deliver on these two quality dimensions, they will have huge positive effect on the consumer's brand attitude; and opposite if the firm is not able to live up to the consumer's expectation. Price has a large, but 
considerably smaller direct effect on brand attitude $(\beta=.16)$, and advertising content and the website's effect are even smaller $\left(\beta=.09\right.$ and $\beta=.04$ respectively). Hence, hypotheses $4 \mathrm{c}_{1}$, $4 c_{2}, 5 c_{2}, 6 c$ and $7 c_{1}$ are supported.

\subsection{PWOM and NWOM's asymmetric influence on consumer responses}

PWOM influences brand attitude positively $(\beta=.17)$, but increases the purchase intention even further $(\beta=.28)$. NWOM has almost no impact on brand attitude $(\beta=-.05)$, but decreases the purchase intention considerably $(\beta=-.22)$ (hypotheses $1,2 \mathrm{a}, 2 \mathrm{~b}, 3 \mathrm{a}$, and $3 \mathrm{~b}$ are supported). Hence, our proposition about PWOM being more influential than NWOM on consumer responses in well-established markets with well-known brands is supported.

\subsection{WOM as a mediator}

PWOM partially mediates product quality and advertising content (mediation share of .18 and .25). That the positive elements in the advertising are perceived sufficient interesting and informative to be discussed in a social context are consistent with Keller Fay Group's (2009) findings, showing that US consumers discuss $20 \%$ of 3.3 billion advertising generated brand impressions each day. Hence, our study documents that adverting content is brought into a social context, where the brand is articulated and added acceptability and own experiences, which then has a positive, direct effect on brand attitude. PWOM mediates store location completely (mediation share .03), i.e., only when other consumers' tell positive things about the firm's stores and where they are located, does it influence brand attitude.

NWOM partially mediates product quality (mediation share .07). The consumers' discuss the negative elements and experiences about the product, which then enhances the product quality's negative impact on brand attitude.

All other marketing activities are not mediated by WOM or the mediation share is small and non-significant. Hence, hypotheses $4 \mathrm{~d}_{2}, 4 \mathrm{e}_{2}, 5 \mathrm{~d}_{2}, 5 \mathrm{e}_{1}, 5 \mathrm{e}_{2}, 6 \mathrm{~d}, 6 \mathrm{e}, 7 \mathrm{~d}_{2}, 7 \mathrm{e}_{1}$ and $7 \mathrm{e}_{2}$ are not supported. 


\section{Discussion and contribution}

This study contributes to the operation of WOM. Our findings show that product quality, advertising content and store location are mediated by PWOM and their impacts are relatively high. NWOM only mediates product quality and the mediation effect is relative small. Hence, PWOM is the main mediator and amplifier of marketing activities.

The distinction between PWOM and NWOM is important, due to their asymmetric influence on consumer responses with PWOM being the main influencer. Hence, on this market firms should primarily focus on increasing PWOM rather than reducing NWOM.

\section{Managerial implications}

It is not surprising that product and service quality plays a crucial role in both the mobilization of WOM and in their influence on brand attitude; the core product is a prerequisite for being on the market. The firm can use this knowledge in situations where the consumer perceives the product as complex and difficult to evaluate, for example for very technical oriented products, intangible services and new products. Here PWOM can translate complex messages to understandable knowledge and relevant decision criteria.

The firms advertising may also be subject to PWOM if the advertising message is designed to create positive ad-talk (see Martensen and Mouritsen 2014). When the advertising message is embedded in WOM, the effect of the firm's advertising campaign is extended beyond the campaign period, prolonging its lifetime.

WOMs mediating effect means that it is no longer sufficient only to study and measure how marketing activities create consumer responses. It is also important to study which activities create PWOM and NWOM and to take their different effects on consumers' responses into account. This gives the firm two interesting challenges. 
The first challenge is to develop (short term) marketing strategies that can mobilize (long term) PWOM which in turn can amplify the marketing activities' effect on consumers' responses. Our findings underline that the complexity in the composition of the 4Ps increases when PWOM is included as a fifth P in the 4Ps marketing strategy that needs to be managed. However, our findings may help marketers to prioritize the 4Ps in their effort to increase PWOM and reduce NWOM.

The second challenge is that of consumers' co-creation of brands. In previous research, this has primarily aimed at innovation. Our research points to the importance of the co-creation that takes place in a WOM context where consumers exchange information, preferences and experiences.

\section{Limitations and future research directions}

This study focuses on one brand. The replicability of this study's findings for other product categories can be questioned, since the marketing activities and type of WOM may be brandor category dependent. Therefore similar studies need to be carried out for other brands and product categories.

Future studies may find it interesting to gain a deeper understanding of what motivates the consumer to seek different sources of WOM. Who are the preferred WOM sources, if the consumer wants to reduce specific types of risks? Studies of strong vs. weak ties could increase the understanding of the various links between source knowledge, expertise and credibility. 


\section{References}

Ahluwalia, Rohini. (2002). How prevalent is the negativity effect in consumer environments? Journal of Consumer Research 29 (2): 270-9.

Ajzen, I. (1991). The theory of planned behavior. Organizational Behavior \& Human Decision Processes, 50(2), 179.

Allsop, D.T., Bassett, B.R., \& Hoskins, J.A. (2007). Word of mouth: Principles and applications. Journal of Advertising Research, 47(4), 398-411.

Arndt, J. (1967). Word of mouth advertising: A review of the literature. New York:

Arora, H. (2007). Word of mouth in the world of marketing. ICFAI Journal of Marketing Management, 6(4), 51-65.

Bayus, B. L. (1985). Word of mouth: The indirect effects of marketing efforts. Journal of Advertising Research, 25(3), 31.

Bearden, W. O., Netemeyer, R. G., \& Teel, J. E. (1989). Measurement of consumer susceptibility to interpersonal influence. Journal of Consumer Research, 15(4), 473-481.

Bone, P. F. (1995). Word-of-mouth effects on short-term and long-term product judgments. Journal of Business Research, 32(3), 213-223.

Bradley, F. (2001). Country-firm interaction effects and supplier preferences among industrial buyers. Industrial Marketing Management, 30, 511-524.

Bradley, F. (2003). Strategic marketing: In the customer driven organization. Chichester: John Wiley and Sons Ltd.

Bristor, J. M. (1990). Enhanced explanations of word of mouth communications: The power of relationships. Research in Consumer Behavior, 4, 51-83.

Bruyn, Arnaud D., and Gary L. Lilien (2008), "A multi-stage model of word-of-mouth influence through viral marketing," International Journal of Research in Marketing, 25, 151-63.

Burzynski, M. H., \& Bayer, D. J. (1977). The effect of positive and negative prior information on motion picture appreciation. Journal of Social Psychology, 101, 215-18.

Canary, D. J., \& Seibold, D. R. (1984). Attitudes and behavior: An annotated bibliography. New York: Praeger.

Cengiz, E., \& Yayla, H. E. (2007). The effect of marketing on positive word of mouth communication: Evidence from accounting offices in turkey. Innovative Marketing, 3(4), 73-85.

Chang, T., \& Wildt, A. R. (1994). Price, product information, and purchase intention: An empirical study. Journal of the Academy of Marketing Science, 22(1), 16-27.

Charlett, D., \& Garland, R. (1995). How damaging is negative word of mouth? Marketing Bulletin, 6, 42.

Chakravarty, A., Young L. and Mazumdar, T.(2010), "The Differential Effects of Online Word-of-Mouth and Critics' Reviews on Pre-release Movie Evaluation", Journal of Interactive Marketing, Vol 24 No. 3, pp.185-197.

Chin, W. W. (1998). The partial least square approach for structural equation modelling. Modern methods for business research (pp. 295). Mahwah, N.J.: Lawrence Erlbaum Association.

Chu, S.-C., and Kim, Y. (2011), "Determinants of consumer engagement in electronic wordof-mouth (eWOM) in social networking sites", International Journal of Advertising, Vol. 30 No. 1, pp. 47-75.Day, G. S. (1971). Attitude change, media and word of mouth. Journal of Advertising Research, 11(6), 31-40.

Coelho, Pedro S. and Esteves, Susana P. (2007). The choice between a five-point and a tenpoint scale in the framework of customer satiscation measurement, International Journal of Market Research. 49(3), 313-339. 
East, R., Gendall, P., Hammond, K., \& Lomax, W. (2005). Consumer loyalty: Singular, additive or interactive. Australasian Marketing Journal, 13(2), 10-26.

East, Robert, Kathy Hammond, and Wendy Lomax (2008), "Measuring the impact of positive and negative word of mouth on brand purchse probability," International Journal of Research in Marketing, 25 (3), 215-24.

Elliott, M. T., \& Speck, P. S. (1998). Consumer perceptions of advertising clutter and its impact across various media. Journal of Advertising Research, 38(1), 29-41.

Engel, J. F., Kegerris, R. J., \& Blackwell, R. D. (1969). Word of mouth communication by the innovator. Journal of Marketing, 33, 15-19.

Fishbein, M., and I. Ajzen (1975), Belief, attitude, intention and behavior, Reading, Massachusetts: Addison-Wesley Publishing Firm.

Fiske, S. T. (1980). Attention and weight in person perception: The impact of negative and extreme behavior. Journal of Personality and Social Psychology, 38(6), 889-906.

Fornell, C., \& Cha, J. (1994). Partial least square. In R. P. Bagozzi (Ed.), Advanced methods of marketing research (pp. 52-78). Cambridge: Blackwell.

Fornell, C., \& Larcker, D. F. (1981). Evaluating structural equation models with unobservable variables and measurement error. Journal of Marketing Research (JMR), 18(1), 39-50.

Fornell, C., M. D. Johnson, E. W. Anderson, J. Cha, and B. E. Bryant (1996), "The American customer satisfaction index: Nature, purpose, and findings," Journal of Marketing, 60 (October), 7-18.

Garvin, D. A. (1984). Product quality: An important strategic weapon. Business Horizons, 27(3), 40 .

Gelb, B., \& Johnson, M. (1995). Word-of-mouth communication: Causes and consequences. Journal of Health Care Marketing, 15(3), 54-58.

Graham, J., \& Havlena, W. (2007). Finding the "missing link": Advertising's impact on word of mouth, web searches, and site visits. Journal of Advertising Research, 47(4), 427-435.

Godes, D. and Mayzlin, D. ( 2004).Using online conversation to study Word-of-Mouth Communication. Marketing Science. 23(4), p545-560

Gupta, S. \& Zeithaml, V. (2006). Customer metrics and their impact on financial performance. Marketing Science, 25(6), 718-739.

Hansen, T., Jensen, J. M., \& Solgaard, H. S. (2004). Predicting online grocery buying intention: A comparison of the theory of reasoned action and the theory of planned behavior. International Journal of Information Management, 24(6), 539-550.

Hennig-Thurau, T., Gwinner, K. P., Walsh, G., \& Gremler, D..D.: "Electronic Word-of-Mouth via consumer-opinion platforms: What Motivates consumers to articulate themselves on the Internet?", Journal of Interactive Marketing, Winter 2004, Vol. 18, No. 1, pp. 38 - 52.

Herr, P. M., Kardes, F. R., \& Kim, J. (1991). Effects of word-of-mouth and product-attribute information of persuasion: An accessibility-diagnosticity perspective. Journal of Consumer Research, 17(4), 454-462.

Hulland, J. (1999). Use of partial least squares (PLS) in strategic management research: A review of four recent.. Strategic Management Journal, 20(2), 195.

Hung, K. H.and Li, Y.S. (2007). The Influence of eWOM on Virtual Consumer Communities: Social Capital, Consumer Learning, and Behavioral Outcomes, Journal of Advertising Research. 47(4), p485-495

Huang, Minxue, Fengyan Cai, Alex S.L. Tsang \& Nan Zhou (2011). Making your online voice loud: the critical role of WOM information, European Journal of Marketing, 45(7/8), 1277-1297.

Kahneman, D., and Tversky, A. (1979). Prospect theory: An analysis of decision under risk. Econometrica, 47(2), 263-291. 
Keller Fay Group. (2009). The steak is the sizzle - A study on product attributes that drive word-of-mouth success.

Keller, E. (2007). Unleashing the power of word of mouth: Creating brand advocacy to drive growth. Journal of Advertising Research, 47(4), 448-452.

Keller, K. L., \& Lehmann, D. R. (2003). How do brands create value? Marketing Management, 12(3), 26-31.

King, K. W., \& Tinkham, S. F. (1989). The learning and retention of outdoor advertising. Journal of Advertising Research, 29(6), 47-51.

Kristensen, K., A. Martensen, and L. Grønholdt (2000), "Customer satisfaction and business performance," in Business performance measurement: Theory and practice, Edited by A. Neely. Cambridge, UK: Cambridge University Press, 279-94.

Lewis, R. C. (1983). When guests complain. Cornell Hotel and Restaurant Administration Quarterly, 24(23), 23-32.

Libai, B., Bolton, R., Bügel, M. S., Ruyter, K. D., Götz, O. and Risselada, H. (2010), "Customer-to-customer interactions: Broadening the scope of word of mouth research", Journal of Service Research, Vol. 13 No. 3, pp. 267-282.

Martensen, A., Grønholdt, L., \& Trajcevski, S. (2004, ). Building customer-brand relationships on the internet: Development of an online brand equity model. Message posted to Forum for Advertising Research

Martensen, A. and J. Mouritsen (2014). How Ad-talk and Word-of-Mouth Influence Consumers' Responses, Innovative Marketing, 10(2), p. 58-69

McCarthy, E. J. (1964). Basic marketing: A managerial approach. Homewood Ill: Irwin.

Monroe, Kent B. and R. Krishman (1983). " A procedure for Integration Outcomes across Studies," in Advances in Consumer Research, vol. 10, ed. Richard P. Bagozzi and Alice M. Tybout (Ann Arbor, MI: Association for Consumer Research), 503-8

Moschis, G. P. (1976). Social comparison and informal group influence. Journal of Marketing Research, 13, 237-244.

Nyilasy, G. (2006). Word of mouth: What we really know -and what we don't. In J. Kirby, \& P. Marsden (Eds.), Connected marketing - the viral,buzz and word og mouth revolution (1.Edition ed., pp. 161-184). The Netherlands: Butterworth-Heinemann.

Parasuraman, A., Zeithaml, V. A., \& Berry, L. L. (1988). SERVQUAL: A multiple-item scale for measuring consumer perceptions of service quality. Journal of Retailing, 64(1), 12-40.

Perreault, W. D., Cannon, J. P., \& McCarthy, E. J. (2008). Basic marketing: A marketing strategy planning approach (16. ed. ed.). Boston: McGraw-Hill/Irwin.

Reinartz, W. J., Haenlein, M. and Henseler, J. (2009), "An empirical comparison of the efficacy of covariance-based and variance-based SEM", International Journal of Research in Marketing, Vol. 26 No. 4, pp. 332-344.

Richins, M. L. (1983). Negative word-of-mouth by dissatisfied consumers: A pilot study. Journal of Marketing, 47(1), 68-78.

Ringle, C., Wende, S., \& Will, A. (2005). SmartPLS 2.0 (M3) beta. Hamburg, Germany:

Rust, R. T., Ambler, T., Carpenter, G. S., Kumar, V., \& Srivastava, R. K. (2004). Measuring marketing productivity: Current knowledge and future directions. Journal of Marketing, 68(4), 76-89.

Sheeran, P., \& Taylor, S. (1999). Predicting intentions to use condoms: A metaanalysis and comparison of the theories of reasoned action and planned behavior. Journal of Applied Psychology, 29, 1624-1675.

Sheppard, B. H., Hartwick, J., \& Warshaw, P. R. (1988). The theory of reasoned action: A meta-analysis of past research with recommendations for modifications and future research. Journal of Consumer Research, 15(3), 325-343. 
Söderlund, M., \& Rosengren, S. (2007). Receiving word-of-mouth from the service customer: An emotion-based effectiveness assessment. Journal of Retailing \& Consumer Services, 14(2), 123-136.

Sweeney, J. C., Soutar, G. N., \& Mazzarol, T. (2008). Factors influencing word of mouth effectiveness: Receiver perspectives. European Journal of Marketing, 42(3), 344-364.

Tenenhaus, M., Vinzi, V. E., Chatelin, Y., \& Lauro, C. (2005). PLS path modeling. Computational Statistics \& Data Analysis, 48(1), 159-205.

Vakratsas, D., \& Ambler, T. (1999). How advertising works: What do we really know? Journal of Marketing, 63(1), 26-43.

Wu, J.-H., \& Wang, S.-C. (2005). What drives mobile commerce?: An empirical evaluation of the revised technology acceptance model. Information and Management, 42(5), 719 729.doi:10.1016/j.im.2004.07.001

Zeithaml, V. A. (1984). Issues in conceptualizing and measuring consumer response to price. Advances in Consumer Research, 11(1), 612-616.

Zeithaml, V. A. (1998). "Consumer Perceptions of Price, Quality and Value: A Means-End Model and Synthesis of Evidence", Journal of Marketing, 52, 2-22. 


\section{Appendix}

\section{Latent variables, measures and reliability statistics}

\begin{tabular}{|c|c|c|c|}
\hline $\begin{array}{l}\text { Construct } \\
\text { (Inspired or based on) }\end{array}$ & Items & Loading & $\begin{array}{l}\text { Composite } \\
\text { reliability } \\
\text { and AVE }\end{array}$ \\
\hline \multirow{8}{*}{$\begin{array}{l}\text { PWOM } \\
\text { (Martensen and } \\
\text { Mouritsen 2014; } \\
\text { Bearden 1989; Moschis } \\
\text { 1976) } \\
\text { Index=67 }\end{array}$} & $\begin{array}{l}\text { To what extent do you agree/disagree that other people tell you positive things } \\
\text { about this mobile brand firm which... }\end{array}$ & & .88 \\
\hline & often tell me positive things about this mobile broad band firm & .85 & \\
\hline & ...more often mention this mobile broad band firm than other suppliers & .86 & \\
\hline & $\begin{array}{l}\text { If I get this mobile broad band firm recommended, I will know that it is a good } \\
\text { choice }\end{array}$ & .41 & \\
\hline & ...influence my opinion about this mobile broad band firm in a positive way & .71 & \\
\hline & ... helps me make a decision about choosing this mobile broad band firm & .63 & \\
\hline & increases the probability of choosing this mobile broad band firm & .74 & \\
\hline & .confirm my choice of supplier of mobile broad band & .81 & \\
\hline \multirow{4}{*}{$\begin{array}{l}\text { (Marte } \\
\text { Mourit } \\
\text { Beard } \\
\text { 1976). }\end{array}$} & $\begin{array}{l}\text { To what extent do you agree/disagree that other people tell you negative things } \\
\text { about this mobile brand firm which... }\end{array}$ & & .91 \\
\hline & often tell me negative things about this mobile broad band firm & .86 & \\
\hline & seldom mention this mobile broad band firm compared to other suppliers & .67 & \\
\hline & If I get this mobile broad band firm dissuaded I will know that it is a bad choice & .56 & \\
\hline \multirow[t]{4}{*}{ Index $=46$} & ..influence my opinion about this mobile broad band firm in a negative way & .71 & \\
\hline & ...helps me make a decision about not choosing this mobile broad band firm & .88 & \\
\hline & ...decreases the probability that I will choose this mobile broad band firm & .85 & \\
\hline & ...makes me consider switching supplier of mobile broad band & .82 & \\
\hline \multirow{11}{*}{$\begin{array}{l}\text { Product quality and } \\
\text { service quality } \\
\text { (Bradley 2001; Zeithaml } \\
\text { 1998). } \\
\text { Index=75; Index=69 }\end{array}$} & To what extent do you agree/disagree, that this firm's mobile broad band & & .93 \\
\hline & ..is of very high standard & .81 & \\
\hline & ..has good functionality (reach, speed, etc.) & .86 & \\
\hline & ..lives up to advertised speed & .91 & \\
\hline & $\ldots$ is innovative & .84 & \\
\hline & ..quickly integrates new technology & .79 & \\
\hline & ...quickly adopts to consumer needs & .72 & \\
\hline & To what extent do you agree/disagree with the following statements: & & $\begin{array}{l}.90 \\
.74\end{array}$ \\
\hline & $\begin{array}{l}\text { The firm's employees assist and are competent in relation to the firm's products and } \\
\text { services }\end{array}$ & .82 & \\
\hline & The personal service is obliging and forthcoming & .89 & \\
\hline & The sales personnel makes me feel confident in the buying situation & .87 & \\
\hline
\end{tabular}




\begin{tabular}{|c|c|c|c|}
\hline $\begin{array}{l}\text { Construct } \\
\text { (Inspired or based on }\end{array}$ & Items & Loading & $\begin{array}{l}\text { Composite } \\
\text { reliability } \\
\text { and AVE }\end{array}$ \\
\hline \multirow{3}{*}{$\begin{array}{l}\text { Promotion (Ad } \\
\text { content and product } \\
\text { communication) }\end{array}$} & To what extent do you agree/disagree that this firm's advertising is .... & & .89 \\
\hline & imaginative and creative & .66 & \\
\hline & trustworthy & .75 & \\
\hline \multirow{8}{*}{$\begin{array}{l}\text { (Bradley 2001; } \\
\text { Martensen and } \\
\text { Mouritsen 2014). } \\
\text { Index=69; Index=70 }\end{array}$} & interest me & .89 & \\
\hline & relevant & .87 & \\
\hline & informative & .78 & \\
\hline & To what extent do you agree/disagree with the following statements: & & .84 \\
\hline & & & .64 \\
\hline & The firm often informs you about its products and services & .83 & \\
\hline & Communication of product information is of a high standard & .90 & \\
\hline & $\begin{array}{l}\text { It is easy to get relevant information about this firm (e.g., products, services, prices } \\
\text { and changes) }\end{array}$ & .65 & \\
\hline \multirow{5}{*}{$\begin{array}{l}\text { Price } \\
\text { (Bradley 2001; } \\
\text { Martensen et al. } \\
\text { 2004). } \\
\text { Index=68 }\end{array}$} & To what extent do you agree/disagree that this firm has & & .87 \\
\hline & .. good offers and discounts & .73 & \\
\hline & ... competitive prices & .81 & \\
\hline & $\ldots$ good terms of payment & .78 & \\
\hline & .. fair prices & .85 & \\
\hline \multirow{3}{*}{$\begin{array}{l}\text { Place (Store location } \\
\text { and web site) }\end{array}$} & To what extent do you agree/disagree that this firm has.. & & $\begin{array}{l}.96 \\
.92\end{array}$ \\
\hline & .. a sufficient number of retail stores & .97 & \\
\hline & $\ldots$ stores are accessible & .95 & \\
\hline \multirow{5}{*}{$\begin{array}{l}\text { (Cengiz and Yayla } \\
\text { 2007; Martensen and } \\
\text { Mouritsen 2014; } \\
\text { Zeithaml 1998) } \\
\text { Index=77; Index=68 }\end{array}$} & & & $\begin{array}{l}.90 \\
.70\end{array}$ \\
\hline & $\ldots$ web sites that makes it easy to find the information I need & .46 & \\
\hline & ...a web site where information is well organized & .95 & \\
\hline & .....a user friendly web site & .97 & \\
\hline & $\begin{array}{l}\text { When I have to choose a mobile broad band supplier I am aware of the firm's web } \\
\text { site }\end{array}$ & .87 & \\
\hline
\end{tabular}




\begin{tabular}{|c|c|c|c|}
\hline $\begin{array}{l}\text { Construct } \\
\text { (Inspired or based on }\end{array}$ & Items & Loading & $\begin{array}{l}\text { Composite } \\
\text { reliability } \\
\text { and AVE }\end{array}$ \\
\hline \multirow{7}{*}{$\begin{array}{l}\text { Brand attitude } \\
\text { (Coelho and Esteves } \\
\text { 2006; Garvin 1984; } \\
\text { Hansen et al 2004). } \\
\text { Index=77; } \mathbf{R}^{2}=. \mathbf{8 1}\end{array}$} & To what extent do you agree/disagree that ... & & .92 \\
\hline & $\begin{array}{l}\ldots \text { this firm is at the leading edge regarding product development with the mobile } \\
\text { broad band area }\end{array}$ & .73 & \\
\hline & $\ldots$ this firm is a trustworthy firm & .84 & \\
\hline & $\ldots$ this firm has a good image/reputation & .85 & \\
\hline & .. this firm has a brand that differentiates from other suppliers & .88 & \\
\hline & .. you all in all relate this firm with something positive & .85 & \\
\hline & ...fits well into my daily life & .76 & \\
\hline Purchase intention & To what extent do you find the following statement likely or unlikely: & & $\begin{array}{l}.90 \\
.70 \\
\end{array}$ \\
\hline $\begin{array}{l}\text { (Hansen et al. 2004; } \\
\text { Shepard et al. 1988) }\end{array}$ & $\begin{array}{l}\text { It is likely that I would choose this firm's mobile broad band if I freely could choose } \\
\text { among the existing suppliers }\end{array}$ & .84 & \\
\hline \multirow[t]{3}{*}{ Index $=83 ; R^{2}=.58$} & $\begin{array}{l}\text { If you should by mobile broad band today, how likely is it that you would choose this } \\
\text { firm as your supplier }\end{array}$ & .93 & \\
\hline & It is likely that I will continue to buy this firm's mobile broad band the next six month & .75 & \\
\hline & $\begin{array}{l}\text { To what extent do you agree/disagree that this firm mobile broad band lives up to } \\
\text { needs and expectations }\end{array}$ & .81 & \\
\hline
\end{tabular}

Note: All survey questions are rated on a seven-point scale, and most of the questions are formulated as statements to which respondents are asked to rate their agreement on a seven-point scale from 'strongly disagree' to 'strongly agree'. 
Table 1

Studies discussing and supporting the proposed hypotheses

\begin{tabular}{|c|c|c|}
\hline Relationship & $\begin{array}{l}\text { Hypo- } \\
\text { thesis }\end{array}$ & Study \\
\hline $\begin{array}{l}\text { Brand attitude } \rightarrow \\
\text { Purchase intention }\end{array}$ & 1 & $\begin{array}{l}\text { Ajzen 1991; Canary and Seibolt 1984; Fishbein and Ajzen 1975; Sheeran and Taylor 1999; } \\
\text { Sheppard et al. } 1988\end{array}$ \\
\hline $\begin{array}{l}\text { Word of Mouth } \rightarrow \\
\text { Brand attitude }\end{array}$ & $2 \mathrm{a}, 3 \mathrm{a}$ & Bone 1995; Burzynski and Bayer 1977; Charlett and Garland 1995; Herr et al. 1991 \\
\hline $\begin{array}{l}\text { Word of Mouth } \rightarrow \\
\text { Purchase intention }\end{array}$ & $2 b, 3 b$ & Arndt 1967; Charlett and Garland 1995; Söderlund and Rosengren 2007 \\
\hline $\begin{array}{c}\text { Promotion } \rightarrow \\
\text { Word of Mouth }\end{array}$ & $7 \mathrm{a}, 7 \mathrm{~b}$ & Bayus 1985; Cengiz and Yayla 2007; Graham and Havlena 2007; King and Tinkham 1989 \\
\hline $\begin{array}{l}\text { Promotion } \rightarrow \\
\text { Brand attitude }\end{array}$ & $7 \mathrm{c}$ & Elliott and Speck 1998; Vakratsas and Ambler 1999 \\
\hline $\begin{array}{l}\text { Product/Service } \rightarrow \\
\text { Word of Mouth }^{2}\end{array}$ & $4 a, 4 b$ & $\begin{array}{l}\text { Arora 2007; Cengiz and Yayla 2007; Engel et al. 1969; Fornell et al. 1996; Kristensen et al. } \\
\text { 2000; Lewis } 1983\end{array}$ \\
\hline $\begin{array}{l}\text { Product/Service } \rightarrow \\
\text { Brand attitude }\end{array}$ & $4 \mathrm{c}$ & Fornell et al.1996; Kristensen et al 2000; Parasuraman et al. 1988; Zeithaml 1998 \\
\hline $\begin{array}{l}\quad \text { Price } \rightarrow \\
\text { Word of Mouth }\end{array}$ & $6 a, 6 b$ & Cengiz and Yayla (2007); Richins (1983) \\
\hline $\begin{array}{l}\text { Price } \rightarrow \text { Brand } \\
\quad \text { attitude }\end{array}$ & $6 c$ & Monroe and Krishman 1983; Zeithaml 1984; \\
\hline $\begin{array}{l}\text { Place } \rightarrow \\
\text { Word of Mouth }\end{array}$ & $5 a, 5 b$ & Cengiz and Yayla (2007); Martensen et al. (2004) ${ }^{3}$ \\
\hline $\begin{array}{l}\text { Place } \rightarrow \\
\text { Brand attitude }\end{array}$ & $5 \mathrm{c}$ & Martensen et al. (2004) \\
\hline
\end{tabular}

\footnotetext{
${ }^{1}$ Most studies seen from a sender's perspective

${ }^{2}$ Most studies seen from a sender's perspective

${ }^{3}$ This study is seen from a sender's perspective, and has only investigated the web site quality's indirect effect on recommendation via brand attitude
} 
Figure 1. Conceptual model of Word-Of-Mouth's (WOM's) mediating effect between marketing activities and consumer responses.

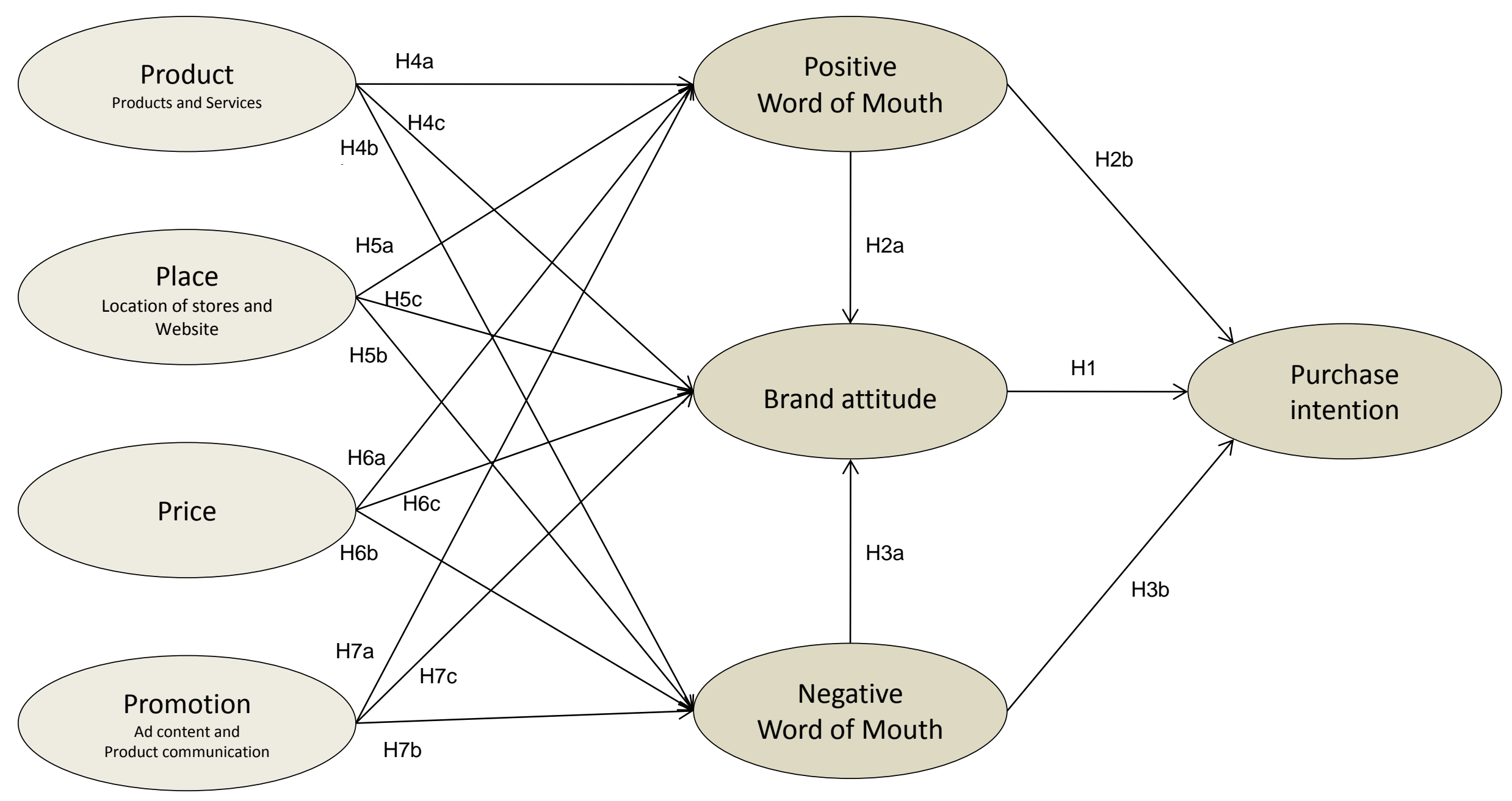


Table 2

\section{Results of the mediation tests}

\begin{tabular}{|c|c|c|c|c|c|c|c|c|}
\hline Hypotheses & $\begin{array}{l}\text { Effect } \\
a \\
(1)\end{array}$ & $\begin{array}{l}\text { Effect } \\
b \\
(2)\end{array}$ & $\begin{array}{l}\text { Total indirect } \\
\text { effect } \\
a b \\
(3)\end{array}$ & $\begin{array}{l}\text { Direct effect } \\
c^{\prime} \\
\text { (4) }\end{array}$ & $\begin{array}{l}\text { Total effect } \\
c=c^{\prime}+a b \\
\text { (5) }\end{array}$ & $\begin{array}{l}\text { Mediation } \\
\text { share } \\
a b /(a b)+c \\
\text { (6) }\end{array}$ & $\begin{array}{l}\text { Sobel's } \\
\text { z-test } \\
\text { (9) }\end{array}$ & $\begin{array}{l}\text { Support or rejection of } \\
\text { hypotheses }\end{array}$ \\
\hline \multicolumn{9}{|l|}{ Product and service quality } \\
\hline 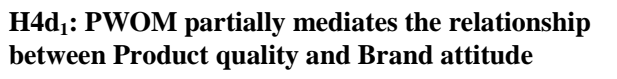 & .36 & .17 & .06 & .27 & .33 & .18 & 4.243 & Partial (Sig) \\
\hline $\begin{array}{l}\mathrm{H}_{4 d_{2}} \text { : PWOM partially mediates the relationship } \\
\text { between Service quality and Brand attitude }\end{array}$ & NS & .17 & 0 & .39 & .39 & 0 & - & No mediation \\
\hline $\begin{array}{l}\mathrm{H}_{1} \mathrm{e}_{1} \text { : NWOM partially mediates the relationship } \\
\text { between Product quality and Brand attitude }\end{array}$ & -.31 & -.05 & .02 & .27 & .29 & .07 & 2.077 & Partial (Sig) \\
\hline $\begin{array}{l}\mathrm{H}_{2} \mathrm{e}_{2} \text { : NWOM partially mediates the relationship } \\
\text { between Service quality and Brand attitude }\end{array}$ & -.09 & -.05 & .005 & .39 & .395 & .01 & 1.488 & Partial (NS) \\
\hline \multicolumn{9}{|l|}{ Place } \\
\hline $\begin{array}{l}\mathrm{HSd}_{1} \text { : PWOM partially mediates the relationship } \\
\text { between Location of stores and Brand attitude }\end{array}$ & .15 & .17 & .03 & NS & .03 & 1 & 4.411 & Complete (Sig) \\
\hline $\begin{array}{l}\mathrm{H5d}_{2}: \text { PWOM partially mediates the relationship } \\
\text { between Firm's website and Brand attitude }\end{array}$ & NS & .17 & 0 & .04 & .04 & 1 & - & No mediation \\
\hline $\begin{array}{l}\mathrm{HS}_{1} \text { : NWOM partially mediates the relationship } \\
\text { between Location of stores and Brand attitude and }\end{array}$ & NS & -.05 & 0 & NS & 0 & 0 & - & No mediation \\
\hline $\begin{array}{l}\mathrm{H5e}_{2} \text { : NWOM partially mediates the relationship } \\
\text { between Firm's website and Brand attitude }\end{array}$ & NS & -.05 & 0 & .04 & .04 & 1 & - & No mediation \\
\hline
\end{tabular}




\begin{tabular}{|c|c|c|c|c|c|c|c|c|}
\hline Hypotheses & $\begin{array}{l}\text { Effect } \\
a \\
(1)\end{array}$ & $\begin{array}{l}\text { Effect } \\
b \\
\text { (2) }\end{array}$ & $\begin{array}{l}\text { Total indirect } \\
\text { effect } \\
a b \\
(3)\end{array}$ & $\begin{array}{l}\text { Direct effect } \\
c^{\prime} \\
(4)\end{array}$ & $\begin{array}{l}\text { Total effect } \\
c=c^{\prime}+a b \\
\text { (5) }\end{array}$ & $\begin{array}{l}\text { Mediation } \\
\text { share } \\
a b /(a b)+c \\
\text { (6) }\end{array}$ & $\begin{array}{l}\text { Sobel's } \\
\text { z-test } \\
\text { (9) }\end{array}$ & $\begin{array}{l}\text { Support or rejection of } \\
\text { hypotheses }\end{array}$ \\
\hline \multicolumn{9}{|l|}{ Price } \\
\hline $\begin{array}{l}\text { H6d: PWOM partially mediates the relationship } \\
\text { between Price and Brand attitude }\end{array}$ & NS & .17 & 0 & .16 & .16 & 1 & - & No mediation \\
\hline $\begin{array}{l}\text { H6e: NWOM partially mediates the relationship } \\
\text { between Price and Brand attitude }\end{array}$ & -.08 & -.05 & .004 & .16 & .164 & .02 & 1.280 & Partial mediation (NS) \\
\hline \multicolumn{9}{|l|}{ Promotion } \\
\hline $\begin{array}{l}\text { H7d } 1 \text { : PWOM partially mediates the relationship } \\
\text { between Advertising content and Brand attitude }\end{array}$ & .19 & .17 & .03 & .09 & .12 & .25 & 2.931 & Partial mediation (Sig) \\
\hline $\begin{array}{l}\mathrm{H7d}_{2} \text { : PWOM partially mediates the relationship } \\
\text { General product communication and Brand } \\
\text { attitude }\end{array}$ & NS & .17 & 0 & NS & - & - & - & No mediation \\
\hline $\begin{array}{l}\text { H7e }: \text { : NWOM partially mediates the relationship } \\
\text { between Advertising content and Brand attitude }\end{array}$ & NS & -.05 & 0 & .09 & .09 & 0 & . & No mediation \\
\hline $\begin{array}{l}\text { H7e } 2 \text { : NWOM partially mediates the relationship } \\
\text { between General product communication and } \\
\text { Brand attitude }\end{array}$ & -.25 & .05 & .01 & NS & .01 & 1 & 1.345 & Complete mediation (NS) \\
\hline
\end{tabular}

